\title{
Aluminum uptake and migration from the soil compartment into Betula pendula for two different environments: a polluted and environmentally protected area of Poland
}

\author{
Marcin Frankowski ${ }^{1}$ (D) \\ Received: 22 June 2015 / Accepted: 3 September 2015 /Published online: 15 September 2015 \\ (C) The Author(s) 2015. This article is published with open access at Springerlink.com
}

\begin{abstract}
This paper presents the impact of soil contamination on aluminum $(\mathrm{Al})$ concentrations in plant parts of Betula pendula and a possible way of migration and transformation of $\mathrm{Al}$ in the soil-root-stem-twig-leaf system. A new procedure of $\mathrm{Al}$ fractionation based on extraction in water phase was applied to obtain and measure the most available forms of $\mathrm{Al}$ in soils and $B$. pendula samples. In addition, total $\mathrm{Al}$ content was determined in biological samples and pseudo total Al content in soil samples collected under plant saplings, using atomic absorption spectrometry with flame atomization. A number of relations concerning the occurrence of $\mathrm{Al}$ and $\mathrm{Ca}$ in soils and plant parts of $B$. pendula (tap roots, lateral roots, stem, twigs, and leaves) were observed. Based on the research findings, the mechanism of Al migration from soil to the leaves of $B$. pendula can be presented. It was found that aluminum uptake may be limited in roots by high calcium concentration. The application of a new procedure based on the simple sequential extraction of water-soluble fractions (the most available and exchangeable fractions of Al) can be used as an effective tool for the estimation of aluminum toxicity in soils and plants.
\end{abstract}

Keywords Aluminum · Fractionation · Soils $\cdot$ Betula pendula $\cdot$ Chemical plant $\cdot$ Wielkopolski National Park

Responsible editor: Elena Maestri

Marcin Frankowski

marcin.frankowski@amu.edu.pl

1 Depatment of Water and Soil Analysis, Adam Mickiewicz University in Poznań, Umultowska 89b, 61-614 Poznań, Poland

\author{
Abbreviations \\ LU Luboń Chemical Plant \\ WNP Wielkopolski National Park \\ PTC Pseudo total content \\ TC Total content \\ F1 Water fraction 1 \\ F2 Water fraction 2 \\ FAAS Flame atomic absorption spectrometry
}

\section{Introduction}

$\mathrm{Al}$ is one of the four most common elements occurring in soils. It is one of the most important components of soils, and to the same extent as silicon, it determines the crystalline frame of soil minerals. Al toxicity is the subject of many papers and reviews (e.g., Berthon 1996; Nayak 2002; Willhite et al. 2014), and research on $\mathrm{Al}$ impact on the environment is commonplace. The main symptom of $\mathrm{Al}$ toxic effects is the dramatic inhibition of root growth, which occurs within minutes after exposure to $\mathrm{Al}$, even at micromolar concentrations (Tanaka et al. 1987; Illèš et al. 2006; Tolrà et al. 2011; Morita et al. 2011). Al toxicity is considered as one of the main factors limiting plant growth in acid soils (comprising about $40 \%$ of the world's arable lands) (Rout et al. 2001; Rezaee et al. 2013; Kovácik et al. 2012; Iqbal 2014). The speciation of Al in soils is a key factor in its potential not only to plant toxicity but also to living organisms as well. Al toxicity in soils and plants is not well understood, and the mechanism of $\mathrm{Al}$ migration is most commonly associated with the organic acid ions of citrate and malate (e.g., Flaten 2002; Fransson et al. 2004; Nunes-Nesi et al. 2014). Several papers describe the impact of $\mathrm{Al}$ on plants based on the use of $\mathrm{Al}$ salts, and most of them mainly focus on the root and its growth (Yang et al. 2013; Kidd and Proctor 2001; Klug et al. 2011; Yan et al. 2012, 
Doshi et al. 2008). It has been found that the occurrence of $\mathrm{Al}$ in soils is strongly connected with $\mathrm{Al}$ in leaves and its speciation (e.g., Frankowski et al. 2013, Karak et al. 2015). Moreover, research on the fractionation of $\mathrm{Al}$ shows that water extract fraction is the most important one due to the availability of $\mathrm{Al}$ species and their possible toxic impact. However, it should be noted that the total content or pseudo total content is important as well (e.g., Milačič et al. 2012; Frankowski et al. 2013). The most frequently used single-step extraction methods for $\mathrm{Al}$ and other elements, including heavy metals or metalloids, include the deionized water method (for the water-soluble fraction). Taking toxicity into account and $\mathrm{Al}$ bioavailability and migration from soils to living organisms, the determination of possible pathways of the migration and accumulation of particular Al species seems necessary. Especially, the mobile $\mathrm{Al}$ species (cold- and warm water-soluble fractions) and the total concentration of $\mathrm{Al}$ should be under focus. Mobile Al fractions are fundamental to learn more about possible pathways of $\mathrm{Al}$ transport in plants. In previous studies, the single-step extraction procedure was used to fractionate $\mathrm{Al}$ in agricultural soils (Takeda et al. 2006), forest soils (Zhu et al. 2004), flood plain soils (Drabek et al. 2005), sedimentary rocks, soils from mining areas (e.g., Matúš et al. 2006; Kubová et al. 2005), and soils from areas polluted with Al (Frankowski et al. 2010; Frankowski and ZiołaFrankowska 2010, Frankowski 2012).

The objectives of this research are to (1) develop the procedure for fractionation of $\mathrm{Al}$ in biological samples, based on water extract fractions, (2) determine the impact of soil contamination on $\mathrm{Al}$ concentration in the plant parts of Betula pendula, (3) determine the correlation of $\mathrm{Al}$ vs. $\mathrm{Ca}$ in soils and particular plant parts of B. pendula, and (4) determine the possible pathway of migration and transformation of $\mathrm{Al}$ in the soil-root-stem-twig-leaf system.

\section{Materials and methods}

Soil and sapling (B. pendula) samples were collected for the analysis during September 2013. The samples of B. pendula (around 3-year-old trees) were divided into five plant parts: (1) twigs, (2) stems, (3) tap roots (without soil particles-removed manually), (4) lateral roots (root and root caps, without soil particles - removed manually), and (5) leaves.

To determine the spatial variability in $\mathrm{Al}$ content/concentration, the study area was divided into two "critical" areas with different $\mathrm{Al}$ concentrations in the soils-Lubon Chemical Plant (LU) and Wielkopolski National Park (WNP) (Fig. 1, Table 1).

LU is located in the southeastern part of the town of Lubon, $2.5 \mathrm{~km}$ south of the artificial recharge well field "Debina" for the city of Poznan (Poland). The plant takes up the area of about 59 ha. To the north of the chemical plant, there are industrial grounds and afforested areas spreading across the meanders of the Warta River. To the south, there is an aggregate mine, and in a distance of about $0.7 \mathrm{~km}$ runs the border of WNP. In a distance of about $200 \mathrm{~m}$ to the southwest of the chemical plant, there is a post-crystallization leachate disposal site. The post-production disposal facility is a dammed-up underground tank with a built-up superstructure, which does not contain any additional safety devices to reduce the migration of pollutants to the water-bearing layer. It takes up the area of about $2 \mathrm{ha}$, and its removal began in the year 2005. The chemical plant produced aluminum fluoride for about 20 years. Post-crystallization leachate generated in the production process was stored at the post-crystallization leachate disposal site in the form of semi-fluid pulp. In the 1980s, such chemicals as superphosphate, hydrofluoric acid, aluminum fluoride, potassium fluoroborate, and vanadium catalyst were also produced there.

Soil samples for the analysis were collected in a depth profile of 0-20 cm. Samples were dried at room temperature. Hygroscopic substances dissolved in water were treated as an integral component of the samples. After drying, each soil sample was sieved through 2.0-, 1.0-, 0.5-, 0.25-, 0.1-, and 0.063$\mathrm{mm}$ mesh size sieves, in accordance with the Polish Standards: PN-ISO 565:2000 and PN-ISO 3310-1:2000, using a LAB-11200/UP sieve shaker (EKO-LAB, Brzesko, Poland). The grain size fraction between 0.1 and $0.25 \mathrm{~mm}$ was predominant and was used to prepare soil extracts. Leaf samples were ground, and the other parts of the trees were divided into $0.5-\mathrm{cm}$ pieces. Subsequently, these samples were stored in polypropylene bags until extraction and mineralization. All the $0.5-\mathrm{cm}$ pieces of particular plant parts were used for extraction.

Fractionation of $\mathrm{Al}$ and $\mathrm{Ca}$ in the water fraction of soils and biological samples:

- Fraction F1: mobile Al obtained by water extraction at room temperature $\left(25^{\circ} \mathrm{C}\right)$ - the most available and mobile form of $\mathrm{Al}$, environmentally available (Frankowski \& Zioła-Frankowska 2010; Frankowski et al. 2013)

- Fraction F2: bound residue of F1—obtained by extraction at $80^{\circ} \mathrm{C}$. An available and partially exchangeable form of $\mathrm{Al}$ (weakly bound to structural parts of biological samples and partially bound on the surface of grains in soil samples)

- TC: total content of structural and mobile forms of $\mathrm{Al}$ and $\mathrm{Ca}$ in biological samples. Total content in the case of $\mathrm{Ca}$ in soils and pseudo total content (PTC) in the case of $\mathrm{Al}$ in soils

The F1 extracts were prepared in a 1:10 $(v / v)$ proportion with deionized water. They were homogenized during $1 \mathrm{~h}$ in a magnetic mixer (the predominant $0.1-0.25-\mathrm{mm}$ grain size fraction was used for the soil samples). Subsequently, the F1 extracts were placed in falcon tubes and a new portion $(10 \mathrm{ml})$ 
Fig. 1 Sampling sites (Luboń Chemical Plant (LU) and Wielkopolski National Park (WNP))

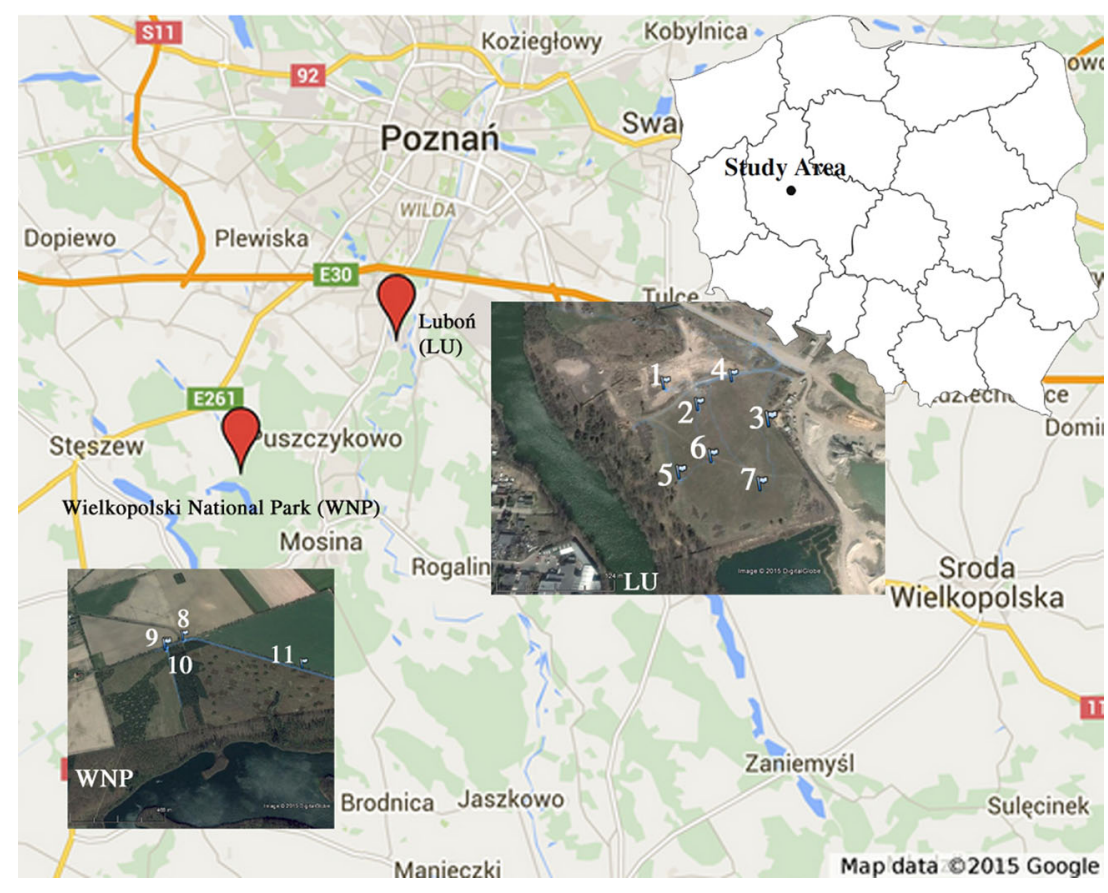

of deionized water was added. During that step, the extraction temperature was increased to $80{ }^{\circ} \mathrm{C}$ (hence named fraction $\mathrm{F} 2$ ). The $\mathrm{pH}$ was determined for all the water extracts, using an Orion 5-star Plus (Thermo, USA) meter with a Single Pore pH electrode (Hamilton, USA). In the next step, the soil samples were mineralized using a modified EPA 3051 method (Frankowski et al. 2013) to separate the pseudo total concentration (PTC) of Al and the total concentration (TC) of Ca. The same method was used for the mineralization of biological samples. Measurements of $\mathrm{Al}$ and $\mathrm{Ca}$ were performed in three replications, and the relative standard deviation did not exceed $7 \%$. The elements were determined using a Shimadzu AA7000 spectrometer (Shimadzu, Japan), with an air- acetylene flame atomization for $\mathrm{Ca}$ and with a nitrous oxideacetylene flame atomization for Al.

To check the accuracy of the flame atomic absorption spectrometry analytical technique, a standard procedure making use of certified reference materials was adopted:

- The SRM 2709_-for soils (soil samples prepared in accordance with EPA method for FAAS)

- The SRM 1515 - for leaves (National Institute of Standards and Technology, USA)

The SRM 2709 and SRM 1515 reference materials were analyzed in six replications. Average recoveries for all the

Table 1 Sampling points

\begin{tabular}{lllll}
\hline Sample no. & Site & \multicolumn{2}{l}{ Coordinates } & \multirow{2}{*}{ Sample collected (separated fractions) } \\
\cline { 3 - 5 } & & $\mathrm{N}$ & \\
\hline 1 & $\mathrm{LU}$ & $52^{\circ} 19^{\prime} 33.48^{\prime \prime}$ & $16^{\circ} 53^{\prime} 43.22^{\prime \prime}$ & \\
2 & $\mathrm{LU}$ & $52^{\circ} 19^{\prime} 32.44^{\prime \prime}$ & $16^{\circ} 53^{\prime} 45.66^{\prime \prime}$ & \\
3 & $\mathrm{LU}$ & $52^{\circ} 19^{\prime} 31.66^{\prime \prime \prime}$ & $16^{\circ} 53^{\prime} 50.47^{\prime \prime}$ & Twigs (F1, F2, TC) \\
4 & $\mathrm{LU}$ & $52^{\circ} 19^{\prime} 33.88^{\prime \prime}$ & $16^{\circ} 53^{\prime} 47.84^{\prime \prime}$ & Stem (F1, F2, TC) \\
5 & $\mathrm{LU}$ & $52^{\circ} 19^{\prime} 29.40^{\prime \prime}$ & $16^{\circ} 53^{\prime} 44.89^{\prime \prime}$ & Tap roots (F1, F2, TC) \\
6 & $\mathrm{LU}$ & $52^{\circ} 19^{\prime} 30.08^{\prime \prime}$ & $16^{\circ} 53^{\prime} 46.82^{\prime \prime}$ & Lateral roots (F1, F2, TC) \\
7 & $\mathrm{LU}$ & $52^{\circ} 19^{\prime} 28.90^{\prime \prime}$ & $16^{\circ} 53^{\prime} 49.96^{\prime \prime}$ & Leaves(F1, F2, TC) \\
8 & $\mathrm{WNP}$ & $52^{\circ} 16^{\prime} 32.19^{\prime \prime}$ & $16^{\circ} 46^{\prime} 32.29^{\prime \prime}$ & Soils (F1, F2, PTC) \\
9 & $\mathrm{WNP}$ & $52^{\circ} 16^{\prime} 30.56^{\prime \prime}$ & $16^{\circ} 46^{\prime} 27.02^{\prime \prime}$ & \\
10 & $\mathrm{WNP}$ & $52^{\circ} 16^{\prime} 29.74^{\prime \prime}$ & $16^{\circ} 46^{\prime} 27.02^{\prime \prime}$ & \\
11 & $\mathrm{WNP}$ & $52^{\circ} 16^{\prime} 25.40^{\prime \prime}$ & $16^{\circ} 47^{\prime} 11.50^{\prime \prime}$ & \\
\hline
\end{tabular}


measured elements in both SRM materials were within range of the certified concentrations.

\section{Results and discussion}

Research on $\mathrm{Al}$ fractionation using single-step extraction and simple sequential extraction of soils and particular plant parts of $B$. pendula indicated the requirement to investigate the issue of $\mathrm{Al}$ availability and bioavailability. This subject has to date been included in the studies by Drabek et al. (2005), Álvarez et al. (2002), Walna et al. (2005), and Zołotajkin et al. (2011). Soil samples most frequently originate from highly acidified areas. Moreover, it should be emphasized that knowledge about $\mathrm{Al}$ availability and bioavailability, from soils through roots and finally to leaves, is important to determine possible toxic effects for plants and possible pathways of $\mathrm{Al}$ transport in the plant system.

\section{Total Al in B. pendula - detailed characterization for different plant organs}

Figure 2 presents the results of total $\mathrm{Al}$ content for particular plant parts of $B$. pendula, for two different types of environments: Luboń Chemical Plant (LU) and Wielkopolski National Park (WNP).

The highest content of $\mathrm{Al}$ was identified in lateral roots, especially in samples taken from the contaminated area (LU). Samples 4 and 7 had Al contents of 3.1 and $4.7 \mathrm{mg} \mathrm{kg}^{-1}$, respectively. The other samples ranged from 463.1 to $1429 \mathrm{mg} \mathrm{kg}^{-1}$ in the LU case and from 289.3 to $419.3 \mathrm{mg} \mathrm{kg}^{-1}$ in the WNP case. Relatively high Al concentrations were found as well in tap root samples taken from the $\mathrm{LU}$ area, ranging from 212.2 to $450.3 \mathrm{mg} \mathrm{kg}^{-1}$, and from the WNP area, ranging from 113.8 to $145.1 \mathrm{mg} \mathrm{kg}^{-1}$. Based on results of $\mathrm{Al}$ measurements in tap roots, we could observe a clear difference between samples, depending on the sampling site (LU or WNP). A similar phenomenon was found for leaves as well, where Al seems to accumulate. In the samples from the contaminated area (LU), $\mathrm{Al}$ content in leaves ranged from 147.3 to $605.7 \mathrm{mg} \mathrm{kg}^{-1}$. The highest $\mathrm{Al}$ content in leaves was determined for sample 7 (also the highest $\mathrm{Al}$ content in lateral root). As for the samples taken from the WNP area, the content of $\mathrm{Al}$ ranged from 12.41 to $55.75 \mathrm{mg} \mathrm{kg}^{-1}$. Similar relations regarding $\mathrm{Al}$ content were found for the samples of other plant organs: twigs and stems. However, for these samples, $\mathrm{Al}$ content was much lower, respectively, in the range $23.5-153.8 \mathrm{mg} \mathrm{kg}^{-1}$ for twig samples taken in the LU area and 9.6-17.1 mg kg${ }^{-1}$ for the samples taken from the WPN area. In the case of stem samples, $\mathrm{Al}$ content ranged from 24.6 to $165.3 \mathrm{mg} \mathrm{kg}^{-1}$ (LU site) and from 9.6 to $22.5 \mathrm{mg} \mathrm{kg}^{-1}$ (WNP site). It was observed that $\mathrm{Al}$ content in stems was lower than in lateral roots (LU site), while for samples collected in the

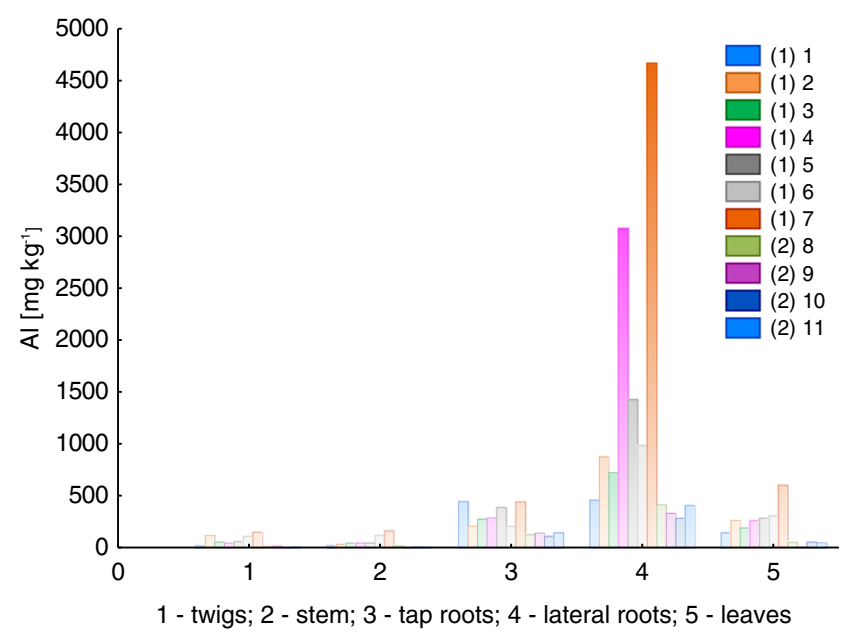

Fig. 2 Total content of aluminum in particular parts of Betula pendula ( $1-11$, samples 1 and 2 mean that they have been collected at the LU and WNP sites, respectively)

WNP site, the dependence of $\mathrm{Al}$ content in stems and lateral roots was not clear; 2 out of 4 samples had higher $\mathrm{Al}$ contents in stems than in lateral roots.

\section{PTC of $\mathrm{Al}$ in soils vs. $\mathrm{Al}$ in $B$. pendula}

Pseudo total content (PTC) of Al represents the fraction occluded on the grains of soils and not bound to the soil crystalline structures. Table 2 presents the concentrations of $\mathrm{Al}$ for the $0.1-0.25-\mathrm{mm}$ grain size fraction and the percentage of $\mathrm{F} 1$ and $\mathrm{F} 2$ fractions in PTC.

PTC for the samples collected in the LU area was variable and averaged to a value of $3601 \mathrm{mg} \mathrm{kg}^{-1}$. The highest concentration was found for sample 5. For the WNP area, Al concentrations were similar, with an average value of $1588 \mathrm{mg} \mathrm{kg}^{-1}$. Still, the contribution of fractions F1 and F2

Table 2 Pseudo total content (PTC) of aluminum $\left(\mathrm{mg} \mathrm{kg}^{-1}\right)$ and the percentage of F1 and F2 fractions in PTC of aluminum in soil samples

\begin{tabular}{llllll}
\hline sample no. & PTC & F1 & F2 & F1 (\%) of PTC & F2 (\%) of PTC \\
\hline $1(1)$ & 2522 & 72.03 & 106.3 & 2.856 & 4.214 \\
$2(1)$ & 2472 & 278.7 & 351.1 & 11.27 & 14.20 \\
$3(1)$ & 4431 & 473.2 & 569.7 & 10.67 & 12.85 \\
$4(1)$ & 3498 & 225.2 & 309.6 & 6.437 & 8.851 \\
$5(1)$ & 6148 & 426.4 & 501.9 & 6.935 & 8.163 \\
$6(1)$ & 4640 & 450.9 & 409.6 & 9.717 & 8.828 \\
$7(1)$ & 1501 & 248.1 & 144.7 & 16.52 & 9.640 \\
$8(2)$ & 1651 & 29.88 & 58.72 & 1.810 & 3.556 \\
$9(2)$ & 1319 & 7.716 & 39.41 & 0.584 & 2.987 \\
$10(2)$ & 1985 & 2.574 & 24.49 & 0.130 & 1.233 \\
$11(2)$ & 1395 & 4.714 & 18.89 & 0.337 & 1.354 \\
\hline
\end{tabular}

Samples 1 and 2 mean that they have been collected at the LU and WNP sites, respectively 
to PTC varied for the samples taken in the LU area. They amounted to $2.9-16.5 \%$ for the F1 and $4.2-14.2 \%$ for the F2 fraction. Samples of soil taken in the WNP site varied as well and amounted to a range of $0.13-1.81 \%$ for the F1 fraction and $1.23-3.56 \%$ for the F2 fraction. The uptake of $\mathrm{Al}$, when based on the PTC of $\mathrm{Al}$ in soils and particular plant organs of B. pendula, is presented in Fig. 3.

Based on the percentage share of Al PTC in soil and TC in B. pendula, it was observed that, except for samples 4 and 7 , the proportions were similar in the LU and WNP areas. It means that the content of $\mathrm{Al}$ in particular plant parts did not depend on soil contamination. The uptake of Al, which was strongly connected with the concentration of $\mathrm{Al}$ in leaves, was evenly distributed in $B$. pendula plant parts, and it was limited by the root system.

\section{F1 in B. pendula—detailed plant organ characterization}

Figure 4 presents $\mathrm{Al}$ concentration in the $\mathrm{F} 1$ fraction, for particular plant parts of $B$. pendula and in two different environment types: LU and WNP.

The $\mathrm{Al}$ concentration in the $\mathrm{F} 1$ fraction demonstrated a similar variability as total content of Al. Fraction F1 is the most mobile fraction of $\mathrm{Al}$, and considering the samples taken at the LU site versus those taken at the WNP site, it can be noted that the availability of $\mathrm{Al}$ for the two areas was different. This refers particularly to the results obtained for leaf samples, in which the $\mathrm{Al}$ concentration was much lower for the WNP site. It can be emphasized as well that $\mathrm{Al}$ concentrations were highest in the lateral and tap roots when compared with the other plant parts of $B$. pendula. This was confirmed by the results for the TC fraction. For lateral root samples, $\mathrm{Al}$ concentrations (in the F1 fraction) of 86.2-640.6 and 12.0$30.3 \mathrm{mg} \mathrm{kg}^{-1}$ were determined, whereas for tap roots, the ranges were as follows: $14.0-175.1$ and $7.9-55.5 \mathrm{mg} \mathrm{kg}^{-1}$ for the LU and WNP sites, respectively. Al concentrations in

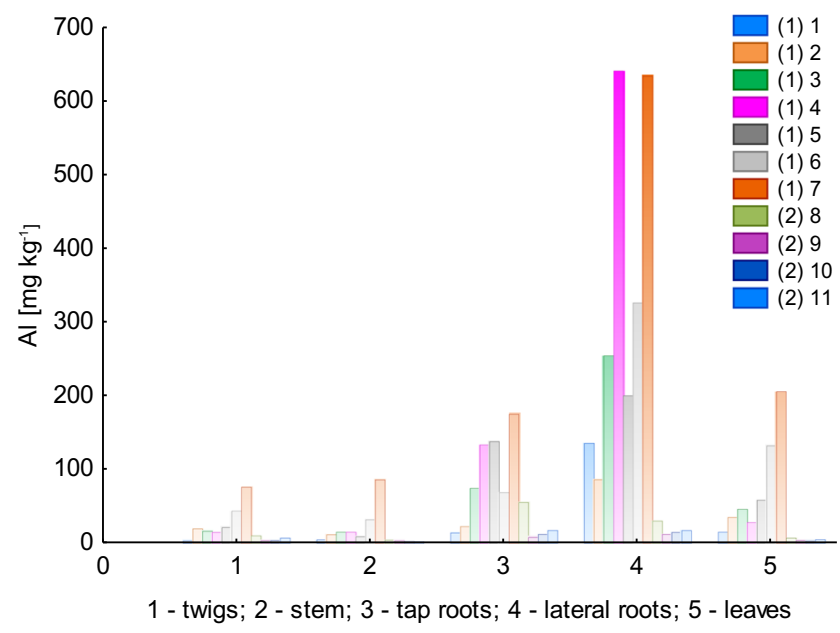

Fig. 4 Concentration of aluminum in the F1 fraction of the particular plant parts of Betula pendula (1-11, samples 1 and 2 mean that they have been collected at the LU and WNP sites, respectively)

leaves ranged from 15.0 to $205.8 \mathrm{mg} \mathrm{kg}^{-1}$ for samples collected at the LU site and from 2.8 to $7.1 \mathrm{mg} \mathrm{kg}^{-1}$ for samples collected in the WNP area. Regarding twigs and stems, the concentration of $\mathrm{Al}$ was lower for stem samples. The concentration ranges were as follows: twigs 3.0-76.0 (LU site) and $3.4-10.1 \mathrm{mg} \mathrm{kg}^{-1}$ (WNP site) and stems $4.9-86.1 \mathrm{mg} \mathrm{kg}^{-1}$ (LU site) and 2.1-4.5 $\mathrm{mg} \mathrm{kg}^{-1}$ (WNP site).

\section{F2 in B. pendula - detailed plant characterization}

Figure 5 presents $\mathrm{Al}$ concentration in the $\mathrm{F} 2$ fraction, for particular plant parts of $B$. pendula and in two different environment types: LU and WNP.

Low $\mathrm{Al}$ concentration in F2 samples of twigs and stems indicated the transport of ions in these plant parts and the accumulation of $\mathrm{Al}$ in leaves. For the $\mathrm{F} 2$ fraction, the $\mathrm{Al}$ concentration in leaves was as follows: $1.3-2.4 \mathrm{mg} \mathrm{kg}^{-1}$ for WNP samples and 9.9-63.1 $\mathrm{mg} \mathrm{kg}^{-1}$ for samples taken at the $\mathrm{LU}$
Fig. 3 Percentage of aluminum in soils and particular plant parts of Betula pendula

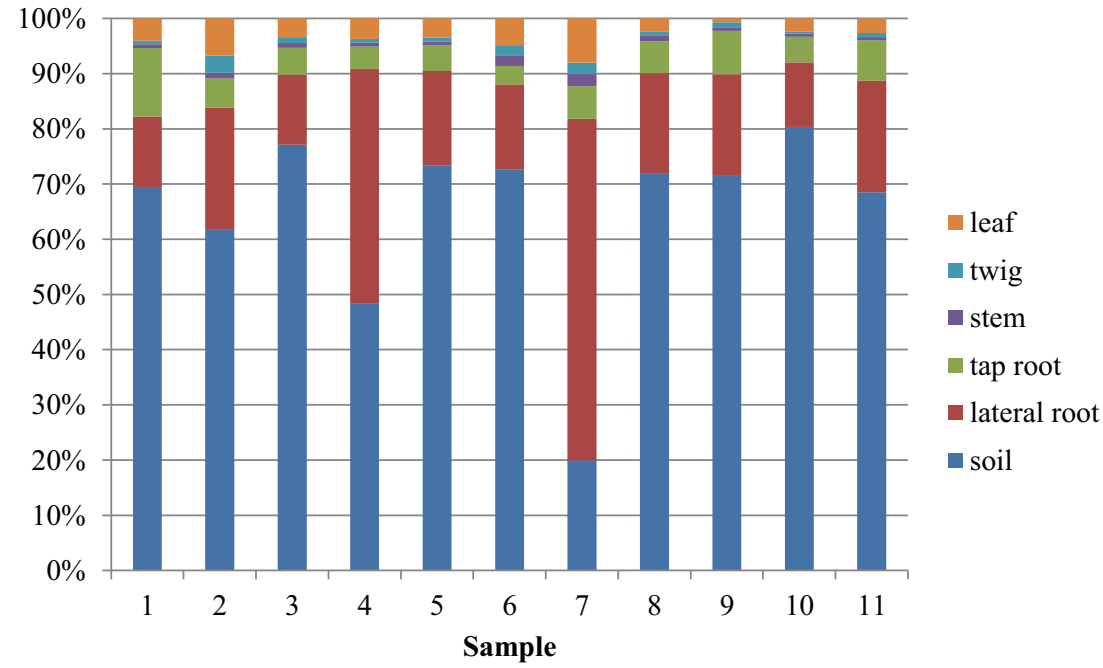




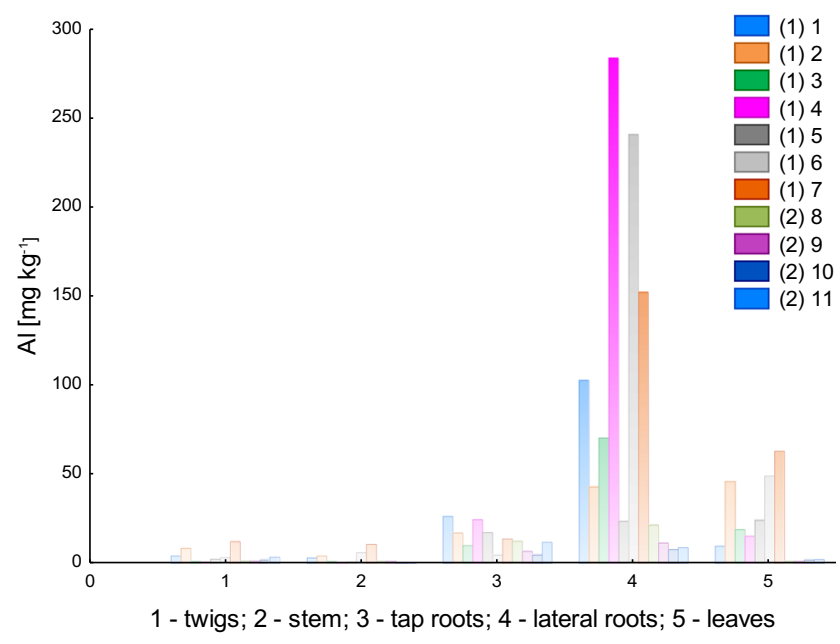

Fig. 5 Concentration of aluminum in the F2 fraction of particular plant parts of Betula pendula (1-11, samples 1 and 2 mean that they have been collected at the LU and WNP sites, respectively)

site. Such a variation of $\mathrm{Al}$ concentrations in the two environment types (LU vs. WNP) suggests the accumulation of $\mathrm{Al}$ with time and binding of $\mathrm{Al}$ to soluble complexes which are not extracted by water during F1 extraction. A similar relation was found for lateral root samples, for which the F2 fraction Al concentrations were as follows: $7.9-21.7 \mathrm{mg} \mathrm{kg}^{-1}$ for the samples taken at the WNP site and 23.8-283.1 mg kg${ }^{-1}$ for the LU site samples. It was observed that the binding of $\mathrm{Al}$ by the specific plant parts was much higher for the samples collected from the LU site than for the samples taken at the WNP site. This suggests the continuous accumulation of $\mathrm{Al}$ during the vegetation season. To determine the degree of $\mathrm{Al}$ binding, the $\%$ value of fraction F1 versus F2 is presented in Fig. 6.

The $\%$ of fraction 1 versus fraction 2 varied, especially for samples 1 and 2 taken at the LU site, in which a higher extraction degree was observed for the F2 fraction than for the other samples taken from that site. Besides, the extraction degree for samples 1 and 2 indicated complex mechanisms of $\mathrm{Al}$ binding to structures of particular plant parts. For samples 3 to 7, the F1 versus F2 variability was similar and the highest $\%$ of the F1/F2 ratio was found in the samples of lateral roots and leaves. In the case of samples taken at the WNP site, the variability in F1/F2 percentage was similar and the tendency for particular plant parts was comparable.

\section{Bioavailability of Al (TC vs. F1)}

The percentage F1 fraction versus TC reflects the availability of $\mathrm{Al}$ which has been transported from the root system to the leaves of $B$. pendula. The variable $\mathrm{F} 1 / \mathrm{TC}$ also indicates the concentration of mobile $\mathrm{Al}$ which is subject to transformations (especially concerning its chemical forms) and contributes to the toxicity of this element. Figure 7 presents the $\%$ share of $\mathrm{F} 1$ in total content of $\mathrm{Al}$ for particular plant parts of B. pendula.

Based on the $\mathrm{F} 1 / \mathrm{TC}$ values of $\mathrm{Al}$, it is difficult to pinpoint a relationship between the results obtained for the LU and WNP sites. This particularly pertains to the values obtained for the samples of twigs and stems. The degree of extraction for these plant parts was variable: $12.7-49.4$ and $17.8-58.8 \%$, respectively, for the LU and WNP site twig samples and 17.1-52.1 and $16.7-31.1 \%$ for the LU and WNP site stem samples. In the other plant parts, i.e., the lateral roots and tap roots, a lower degree of the extraction of $\mathrm{F} 1$ in relation to $\mathrm{TC}$ was observed, especially for samples 9-11 (WNP site). In the case of leaf samples, it was observed that variability was low in the extraction efficiency, indicating the presence of weakly bound $\mathrm{Al}$, e.g., organic $\mathrm{Al}$ complexes.

\section{The impact of pH}

The concentration of $\left[\mathrm{H}^{+}\right]$ions in the F1 fraction for all samples (different plant parts) was similar for the WNP and LU
Fig. 6 The percentage of F1 and F2 fractions (symbol 1.I means sample.plant part: I twigs, II stem, $I I I$ tap roots, $I V$ lateral roots, and $V$ leaves)

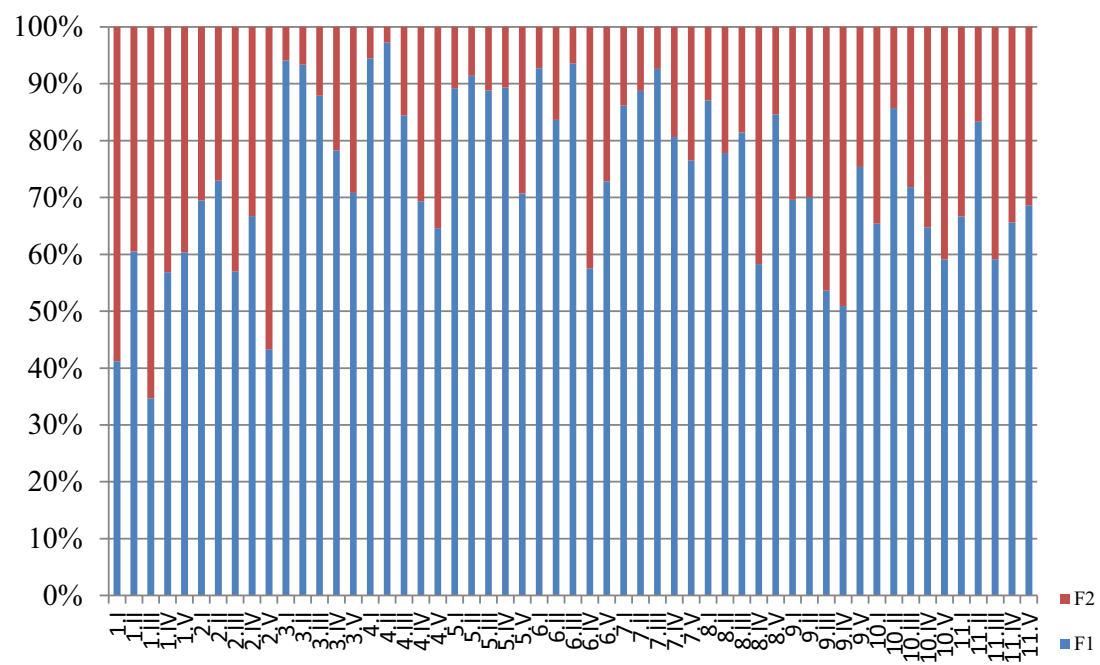




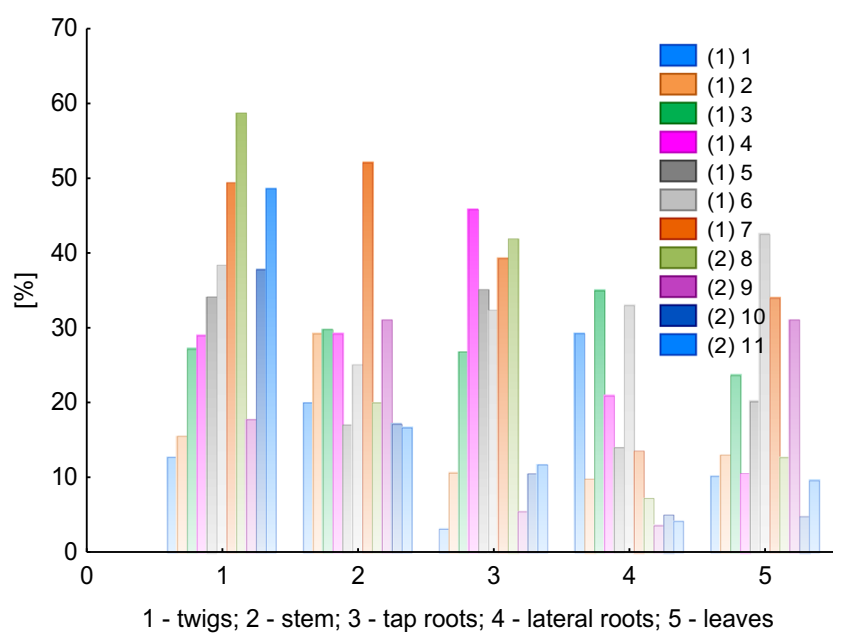

Fig. 7 The percentage of fraction F1 with respect to the total content of aluminum in particular plant parts of Betula pendula (1-11, samples 1 and 2 mean that they have been collected at the LU and WNP sites, respectively)

sites (Fig. 8). However, pH variability in samples of leaf water extracts, taking values from 3.9 to 6.7 for the LU site and from 4.1 to 4.8 for the WNP site, should be further discussed.

Low $\mathrm{pH}$ values in leaf samples can be explained by the occurrence of organic acids in leaves, which - depending on the concentration of ligands (e.g., oxalate, citrate, malonate, acetate, formate) - can lower $\mathrm{Al}$ toxicity by the formation of relatively stable $\mathrm{Al}$ complexes with a considerable advantage of the ligand $/ \mathrm{Al}^{3+}$. Expressed toxic impacts at low contributions of the ligand $/ \mathrm{Al}^{3+}$ are a consequence of low ligand occurrence (e.g., Frankowski et al. 2013).

\section{TC of Ca vs. $\mathrm{Al}$ in soils and B. pendula}

The total content of $\mathrm{Ca}$ was higher in samples of $B$. pendula than in soils. The variability of $\mathrm{Ca}$ concentrations in particular

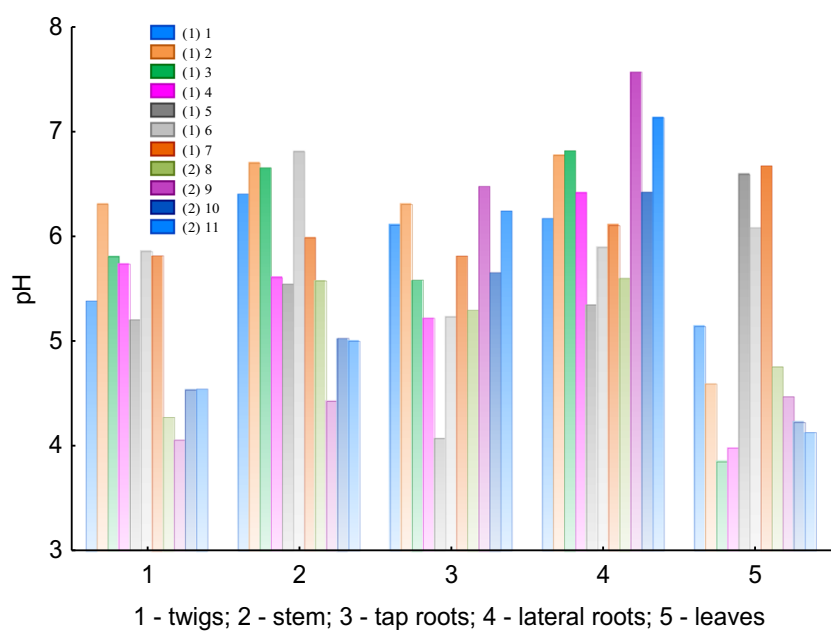

Fig. $8 \mathrm{pH}$ values for particular plant parts of Betula pendula samples in the $\mathrm{F} 1$ fraction $(1-11$, samples 1 and 2 mean that they have been collected at the LU and WNP sites, respectively) plant parts was similar to that of $\mathrm{Al}$ concentrations (for both the F1 and F2 fractions and PTC). This relationship indicates a strong connection between the occurrence of $\mathrm{Ca}$ and $\mathrm{Al}$ in soils as well as similar mechanisms of uptake by the plant root system and transport to leaves. Table 3 presents the TC of $\mathrm{Ca}$ determined for particular plant parts and the concentration of $\mathrm{Ca}$ in soils.

To determine and open the discussion on the dependences of the occurrence of $\mathrm{Ca}$ and $\mathrm{Al}$ in soils and in particular plant parts, correlations are presented for each group of samples (Fig. 9).

The results obtained for soil samples showed that concentrations of $\mathrm{Al}$ were highly dependent on the concentration of $\mathrm{Ca}(r=0.969)$. This allows us to state that the availability of $\mathrm{Ca}$ and $\mathrm{Al}$ cations was regulated in the soil. $\mathrm{Ca}$ is taken up from soils through the root system, first, through the lateral roots and, subsequently, by the tap roots. With regard to the relationship between $\mathrm{Al}$ and $\mathrm{Ca}$ in lateral roots, it was found that $\mathrm{Al}^{3+}$ cations were "blocked," and as a result, $\mathrm{Ca}^{2+}$ cations were introduced. First of all, this can be explained by the much lower concentration of $\mathrm{Ca}$ in the lateral root system than in tap roots, combined with the retention of $\mathrm{Ca}$ in the root system. In this case, lateral roots prevented the introduction of $\mathrm{Al}$ to tap roots and with respect to transport, further to the stems and twigs and finally to the leaves. The process was limited by the uptake of higher amounts of $\mathrm{Ca}^{2+}$ by the system. This was confirmed by the results of the $\mathrm{Ca} / \mathrm{Al}$ correlation for tap roots. We obtained much higher values of coefficient $r=0.736$ as compared to later roots. On that basis, it can be assumed that $\mathrm{Al}$ does not migrate from soils to roots as $\mathrm{Al}^{3+}$ but in other speciations, i.e., $\mathrm{Al}$ complexes which are both of inorganic and organic nature and with a different charge (e.g., $+1,-1$, and $+2,-2$ ). Also emphasized is that the correlation study results for tap roots showed that $B$. pendula plants are able

Table 3 Total content of $\mathrm{Ca}\left(\mathrm{mg} \mathrm{kg}^{-1}\right)$ in particular plant parts of Betula pendula and in soil samples

\begin{tabular}{lllllll}
\hline Sample no. & Twig & Stem & Tap root & Lateral root & Leaf & Soil \\
\hline $1(1)$ & 4844 & 6232 & 9767 & 9094 & 9146 & 2075 \\
$2(1)$ & 7942 & 4367 & 5242 & 6611 & 9812 & 2712 \\
$3(1)$ & 6677 & 3887 & 7446 & 6562 & 7343 & 3324 \\
$4(1)$ & 6168 & 4733 & 6455 & 7794 & 8275 & 2540 \\
$5(1)$ & 5210 & 4300 & 7020 & 8049 & 7683 & 5211 \\
$6(1)$ & 5963 & 5531 & 6076 & 5962 & 9281 & 3636 \\
$7(1)$ & 4063 & 3916 & 5714 & 8691 & 11,930 & 628.4 \\
$8(2)$ & 4942 & 2845 & 5756 & 5518 & 7413 & 556.1 \\
$9(2)$ & 2952 & 2245 & 2818 & 3467 & 4896 & 294.9 \\
$10(2)$ & 3387 & 2169 & 3212 & 3981 & 6278 & 957.7 \\
$11(2)$ & 3067 & 2590 & 5115 & 5811 & 5782 & 334.7 \\
\hline
\end{tabular}

Samples 1 and 2 mean that they have been collected at the LU and WNP sites, respectively 


\section{twigs}

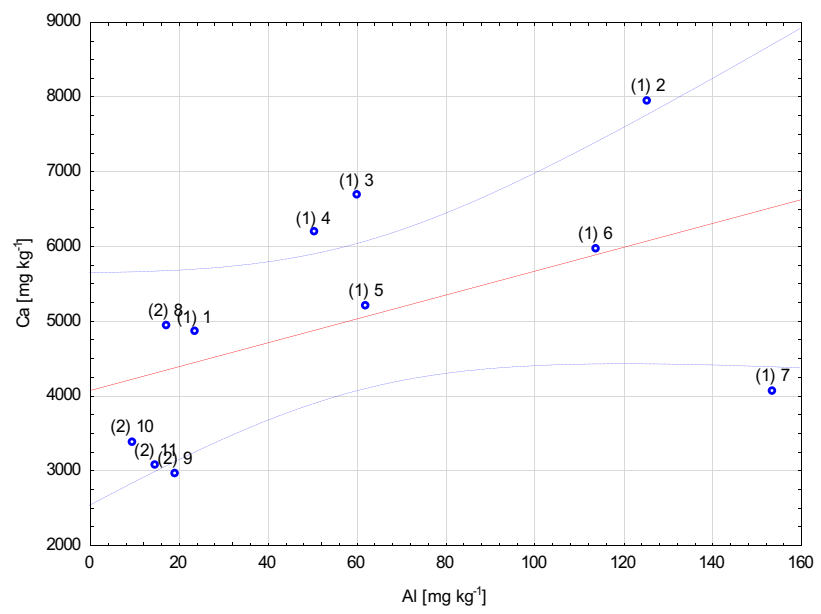

tap roots

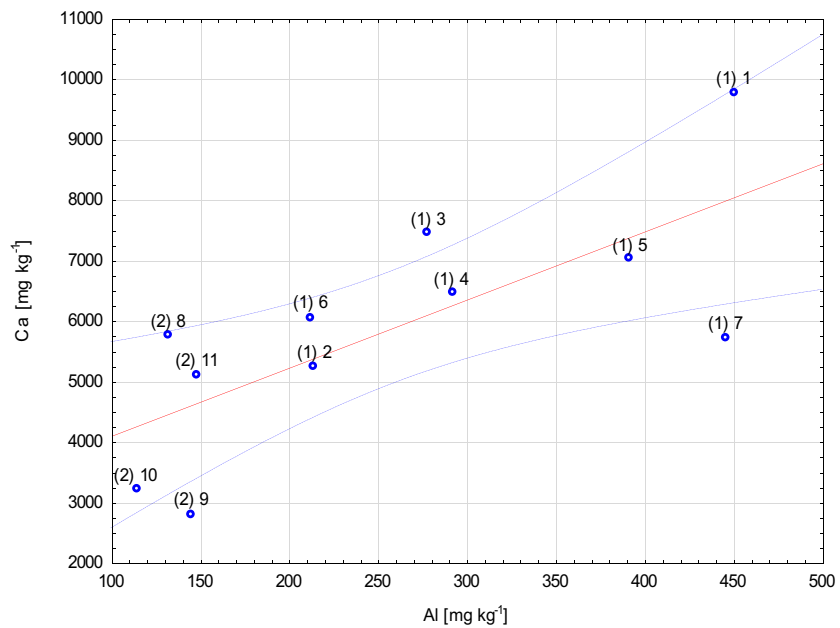

leaves

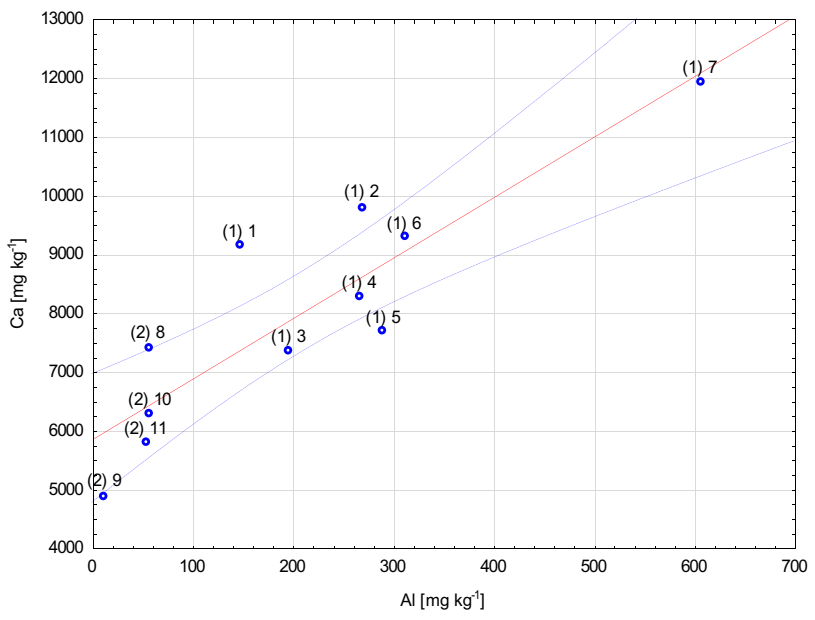

stem

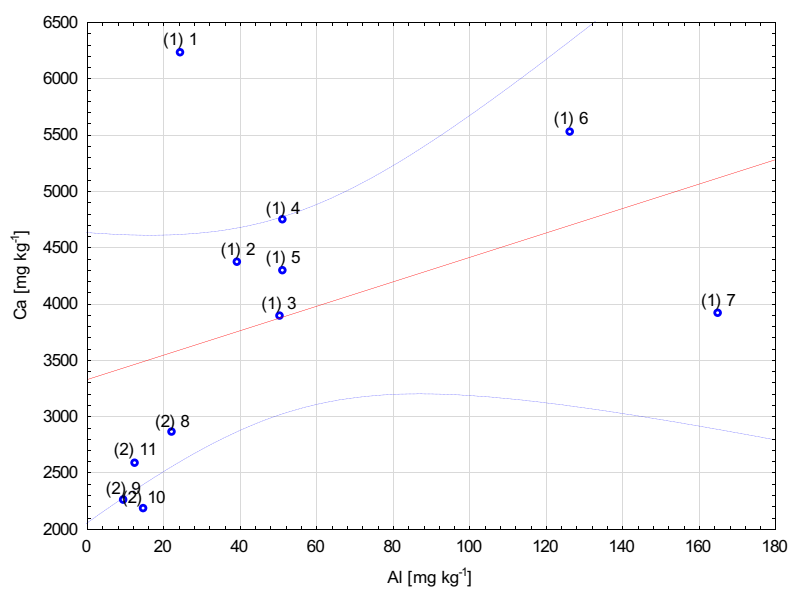

lateral roots

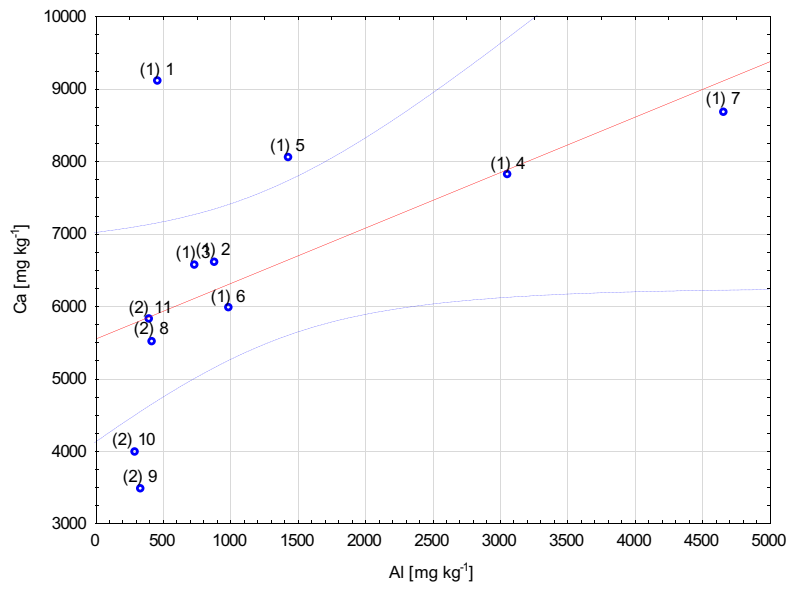

soils

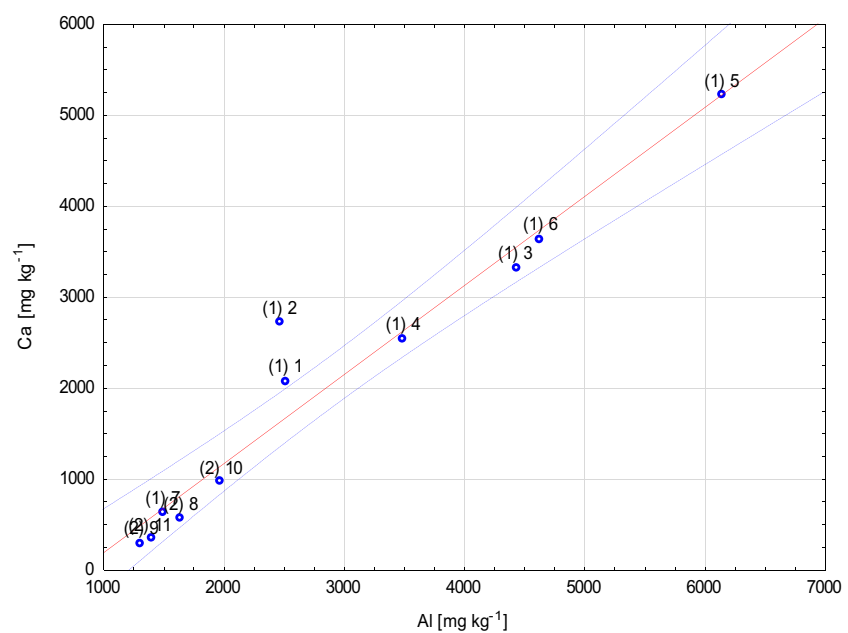

Fig. 9 Graphs representing the correlations of $\mathrm{Al}$ and $\mathrm{Ca}$ concentrations for twigs, stem, tap roots, lateral roots, leaves, and soil samples (significance level $p=0.95$ )

to regulate the concentration of $\mathrm{Ca}$ versus that of $\mathrm{Al}$; this was evident for both the samples taken from the LU site and those from the WNP site. The relationship between $\mathrm{Al}$ and $\mathrm{Ca}$ in stem and twig samples was disturbed, which might be 
connected with the transport of the cations toward the leaves. The results of $\mathrm{Ca}$ and $\mathrm{Al}$ concentrations for leaves and the correlation between these elements $(r=0.882)$ showed that $\mathrm{Al}$ can easily migrate from tap roots to leaves. A specific amount of $\mathrm{Al}$ was built in as a structural element, and a considerable amount was transported to the leaves (see Fig. 5). Taking the $\mathrm{pH}$ of the water extracts of leaf samples into account (Fig. 8), it can be noted that $\mathrm{Al}$ species can be transformed, especially to the $\mathrm{Al}^{3+}$ species. The toxic impact of this $\mathrm{Al}$ form is probably lowered by the availability of organic ligands (e.g., malate, oxalate, or citrate ions). As it is commonly known, organic complexes of $\mathrm{Al}$ are much less toxic or not toxic at all for plants or living organisms. Similar relationships between $\mathrm{Al}$ and $\mathrm{Ca}$ concentrations were observed for both the $\mathrm{F} 1$ and $\mathrm{F} 2$ fractions.

Kidd and Proctor (2001) conducted research on the impact of $\mathrm{Al}$ on growth and mineral composition of $B$. pendula Roth and concluded that low $\mathrm{Al}$ concentrations ( 2 and $5 \mathrm{mg} \mathrm{l}^{-1}$ ) enhanced growth, whereas higher $\mathrm{Al}$ concentrations (10$15 \mathrm{mg} \mathrm{l}^{-1}$ ) reduced growth in less Al-tolerant plant races.

\section{Statistical analysis}

The statistical analysis of $\mathrm{Al}$ concentrations in the F1 and F2 fractions as well as the $\mathrm{TC}$ of $\mathrm{Al}$ in soils and particular plant parts of B. pendula, based on the Kolmogorov-Smirnov test, did not give ground to reject the hypothesis on the equality of means in the studied groups of samples. Similarly, the Shapiro-Wilk test indicated that 11 out of 18 types of soil samples and plant parts (F1, F2, and TC fractions) were characterized by a normal distribution. The samples of tap root F1 and soil F1 fractions as well as tap root F2 and the TC fractions of twig, tap root, leaf, and soil samples (in total, 7 out of 18 types) were not normally distributed (level of significance $p<0.05$ ). To compare the concentration of $\mathrm{Al}$ in the study sites (LU vs. WNP), the $U$ Mann-Whitney test was executed. For $\mathrm{Al}$ in soils and B. pendula, the obtained values of $p$ were lower than $\alpha=0.05$, except for twig F1 fraction and twig, stem, and tap root $\mathrm{F} 2$ fractions. These results led to the conclusion that the $\mathrm{Al}$ concentrations in the $\mathrm{F} 1, \mathrm{~F} 2$, and the $\mathrm{TC}$ fractions of $\mathrm{Al}$ were statistically significantly different for both the investigated sample sites (LU and WNP).

\section{Conclusions}

The application of a new procedure, based on the simple sequential extraction of water-soluble fractions (F1 and F2), can be used as an effective tool for the estimation of soil $\mathrm{Al}$ toxicity in plants. Moreover, it can be emphasized that data on total (plants) and pseudo total (soil) content of $\mathrm{Al}$ are important indeed and should always be taken into account when performing $\mathrm{Al}$ (toxicity) research. Additionally, it can be concluded that the proposed procedure is useful in evaluation of the distribution of $\mathrm{Al}$ in soils and plants. It was elicited that in the samples originating from the LU site, binding of $\mathrm{Al}$ by particular plant parts is much higher than in the samples taken from the WNP sampling site. This suggests a persistent accumulation of $\mathrm{Al}$ during the growing season. The concentration of $\mathrm{Ca}$ in plants and soils was used to understand the mechanism of Al migration from soil to leaves through the plant system. It was observed that the variability of $\mathrm{Al}$ in particular plant parts and the concentration of $\mathrm{Al}$ do not depend on soil contamination. However, based on a statistical analysis, the differences between samples collected from the LU and WNP were indicated. The uptake of $\mathrm{Al}$ was evenly distributed in $B$. pendula plant parts and was limited by the root system as well as strongly connected with the concentration of $\mathrm{Al}$ in leaves.

Acknowledgments The research was supported by the National Science Centre in Poland (project no. DEC-2012/07/D/NZ8/01030).

Conflict of interest Dr. Marcin Frankowski declares that he has no conflict of interest.

Open Access This article is distributed under the terms of the Creative Commons Attribution 4.0 International License (http:// creativecommons.org/licenses/by/4.0/), which permits unrestricted use, distribution, and reproduction in any medium, provided you give appropriate credit to the original author(s) and the source, provide a link to the Creative Commons license, and indicate if changes were made.

\section{References}

Álvarez E, Monterosso ML, Macros F (2002) Aluminium fractionation in Galician (NW Spain) forest soil as related to vegetation and parent material. Forest Ecol Manag 166:193-206

Berthon G (1996) Chemical speciation studies in relation to aluminium metabolism and toxicity. Coord Chem Rev 149:241-280

Doshi R, Braida W, Christodoulatos C, Wazne M, O'Connor G (2008) Nano-aluminium: transport through sand columns and environmental effects on plants and soil communities. Environ Res 106:296303

Drabek O, Mladkova L, Boruvka L, Syakowa J, Nikodem A, Nemecek K (2005) Comparison of water-soluble and exchangeable forms of $\mathrm{Al}$ in acid forest soils. J Inorg Biochem 99:1788-1795

Flaten TP (2002) Aluminium in tea - concentrations, speciation and bioavailability. Coord Chem Rev 228:385-395

Frankowski M (2012) Simultaneous determination of aluminium, aluminium fluoride complexes and iron in groundwater samples by new HPLC-UVVIS method. Microchem J 101:80-86

Frankowski M, Zioła-Frankowska A (2010) Speciation analysis of aluminium and aluminium fluoride complexes by HPIC-UVVIS. Talanta 82:1763-1769

Frankowski M, Zioła-Frankowska A, Siepak J (2010) Speciation of aluminium fluoride complexes and $\mathrm{Al}^{3+}$ in soils from the vicinity of an aluminium smelter plant by hyphenated high performance ion chromatography flame atomic absorption spectrometry technique. Microchem J 95:366-372 
Frankowski M, Zioła-Frankowska A, Siepak J (2013) From soil to leaves - aluminium fractionation by single step extraction procedures in polluted and protected areas. J Environ Manag 127:1-9

Fransson AM, Vinogradoff S, Godbold DL, van Hees PAW, Jones DL (2004) Aluminum complexation suppresses citrate uptake by acid forest soil microorganisms. Soil Biol Biochem 36:353-357

Illěš P, Schlicht M, Pavlovkin J, Lichtscheidl I, Baluška F, Ovečka M (2006) Aluminium toxicity in plants: internalization of aluminium into cells of the transition zone in Arabidopsis root apices related to changes in plasma membrane potential, endosomal behavior, and nitric oxide production. Experimental Botany 57:4201-4213

Iqbal T (2014) A split-root experiment shows that translocated phosphorus does not alleviate aluminium toxicity within plant tissue. Plant Soil 384:21-36

Karak T, Sonar I, Paul RK, Frankowski M, Boruah RK, Dutta AK, Das DK (2015) Aluminium dynamics from soil to tea plant (Camellia sinensis L.): is it enhanced by municipal solid waste compost application? Chemosphere 119:917-926

Kidd PS, Proctor J (2001) Why plants grow poorly on very acid soils: are ecologists missing the obvious? J Exp Bot 52:791-799

Klug B, Specht A, Horst WJ (2011) Aluminium localization in root tips of the aluminium-accumulating plant species buckwheat (Fagopyrum esculentum Moench). J Exp Bot 62:5453-5462

Kovácik J, Stork F, Klejdus B, Jiri GJ, Hedbavny J (2012) Effect of metabolic regulators on aluminium uptake and toxicity in Matricaria chamomilla plants. Plant Physiol Biochem 54:140-148

Kubová J, Matúš P, Bujdoš M, Medved J (2005) Influence of acid mining activity on release of aluminium to the environment. Anal Chim 547:119-125

Matúš P, Kubová J, Bujdoš M, Medved J (2006) Free aluminium extraction from various reference materials and acid soils with relation to plant availability. Talanta 70:996-1005

Milačič R, Zuliani T, Ščančar J (2012) Environmental impact of toxic elements in red mud studied by fractionation and speciation procedures. Sci Total Environ 426:359-365

Morita A, Yanagisawa O, Maeda S, Takatsu S, Ikka T (2011) Tea plant (Camellia sinensis L.) roots secrete oxalic acid and caffeine into medium containing aluminium. Soil Sci Plant Nutri 57:796-802

Nayak P (2002) Aluminium: Impacts and Disease. Environ Res 89:101115

Nunes-Nesi A, Florian A, Howden A, Jahnke K, Stefan TK, Bauwe H, Sweetlove L, Fernie AR (2014) Is there a metabolic requirement for photorespiratory enzyme activities in heterotrophic tissues? Mol Plant 7:248-251

Rezaee F, Ghanati F, Behmanesh M (2013) Antioxidant activity and expression of catalase gene of (Eustoma grandiflorum $\mathrm{L}$ ) in response to boron and aluminium. S Afr J Bot 84:13-18

Rout GR, Samatary S, Das P (2001) Aluminium toxicity in plants: a review. Agronomie 21:3-21

Takeda A, Tsukada H, Takaku Y, Hisamatsu S, Inaba J, Nanzyo M (2006) Extractability of major and trace elements from agricultural soils using chemical extraction methods: application for phytoavailability assessment. Soil Sci Plant Nutr 52:406-417

Tanaka A, Tadano T, Yamamoto K, Kanamura N (1987) Comparison of toxicity to plants among $\mathrm{Al}^{3+}, \mathrm{AlSO}_{4}{ }^{+}$, and $\mathrm{Al}-\mathrm{F}$ complex ions. Soil Sci Plant Nutr 33:43-55.

Tolrà R, Vogel-Mikuš K, Hajiboland R, Kump P, Pongrac P, Kaulich B, Gianoncelli A, Babin V, Barceló J, Regvar M, Poschenrieder C (2011) Localization of aluminium in tea (Camellia sinensis) leaves using low energy X-ray fluorescence spectro-microscopy. J Plant Res 124:165-172

Walna B, Spychalski W, Siepak J (2005) Assessment of potentially reactive pools of aluminium in poor forest soils using two methods of fractionation analysis. J Inorg Biochem 99:1807-1816

Willhite CC, Karyakina NA, Yokel RA, Yenugadhati N, Wisniewski TM, Arnold IMF, Momoli F, Krewski D (2014) Systematic review of potential health risks posed by pharmaceutical, occupational and consumer exposures to metallic and nanoscale aluminium, aluminium oxides, aluminium hydroxide and its soluble salts. Crit Rev Toxicol 44:1-80

Yan J, Chen J, Yu L, Liu J (2012) Aluminium tolerance in Centipedegrass (Eremochloa ophiuroides [Munro] Hack.): excluding Al from root. Sci Hortic 143:12-219

Yang LT, Qi YP, Jiang HX, Chen LS (2013) Roles of organic acid anion secretion in aluminium tolerance of higher plants. Biomed Res Int. doi: $10.1155 / 2013 / 173682$

Zhu M, Jiang X, Ji G (2004) Experimental investigation on aluminium release from haplic acrisols in southeastern China. Appl Geochem 19:981-990

Zołotajkin M, Ciba J, Kluczka J, Skwira M, Smoliński A (2011) Mobile aluminium in the mountain forest soil of Barania Góra range (Silesian Beskids, Poland). Water Air Soil Poll 216:571-580 